\title{
The Response of Stream Competence to Topographic and Seasonal Variations in The Bamenda-Menchum Drainage Basin, North West Region, Cameroon
}

\author{
Kang Edwin Mua ${ }^{1} \&$ Kometa Sunday Shende ${ }^{1}$ \\ ${ }^{1}$ Department of Geography, University of Bamenda, Cameroon \\ Correspondence: Kometa Sunday Shende, Department of Geography, University of Bamenda, Cameroon. E-mail: \\ chevalsk@yahoo.com
}

Received: January 3, 2019

Accepted: Fenruary 4, 2019 Online Published: May 30, 2019

doi:10.5539/jgg.v11n2p21

URL: http://dx.doi.org/10.5539/jgg.v11n2p21

\begin{abstract}
The flow direction of streams remains an establishing mechanism in understanding drainage basin function and stream competence. The ability of streams to erode, transport and deposit loads in fluvial geomorphology exert a benchmark precursor for slope dynamics given the differential geological outcrop of the Bamenda-Menchum basin Such competence in stream network generates slope instability as materials continuously move down slope from the volcanic escarpment face of Bamenda highlands to the sedimentary lowland area of Lower Bafut-Menchum basin. This paper investigate the influence of stream flow direction and stream competence on slope dynamics and how such dynamism affects the development prospects of the drainage basin. Slope range was obtained from AVL/EBI.JHO measurement. Stream length, density and flow direction were gotten from GIS Arc 21. Stream depth, channel width, flow rate and sedimentation levels were measured. Gully depth on slopes and landslide angles were measured using $30 \mathrm{~m}$ tape and a graduated pole. Questionnaires were used to collect information on the vulnerability of households to slope dynamics orchestrated by stream competence. Findings revealed that stream competence varies from the two geological basements and that the escarpment face respond to high flow gravity and hydraulic action contributing to rapid erosion and transportation of loads. The results equally showed that the Bamenda escarpment face that is linked to the crystalline rocks produce differential erosion and landslide. $76.7 \%$ of slope instability is explained by geological structure and seasonality effect in the basin while $23.3 \%$ of slope dynamics is explained by other variables not specified in the study. The lower basin remains liable to deposition of materials on river channels and flood plain. The accumulation of sand, stones and alluvial deposits are extracted and exploited for the development prospects of the basin. The study recommends channel and slope management by integrating slope development control policy in drainage basin management and development.
\end{abstract}

Keywords: integrating slope development control policy, channel and slope management

\section{Introduction}

Hydrological response of drainage basins when considered at a global scale is the production of runoff from a basin specific rainfall, which is characterized by basin morphometric properties, soil characteristics and land use pattern (Yahya, et al. 2016). While soil characteristics and land use pattern directly determine the infiltration loss, the spatial distribution of the excess rainfall on the surface is governed by basin morphometric properties. The drainage basin area is the most important of all the morphometric parameters controlling catchment runoff pattern. It has been established that the larger the basin, the greater the volume of intercepted rainfall and obviously, the higher the peak discharge that results (Adegoke and Bulus, 2015). Rainfall intensity, land use change and various engineering applications on river channels contribute to the magnitude and frequency of flood events. Tributaries from the surrounding watershed channels contribute to erosion and the occurrence of downstream flooding in river basins (Tumpa and Srimanta, 2015). For this reason, information on topographic characteristics of a watershed helps in determining runoff and sedimentation to the outlet of the watershed. The characterized watershed is also essential to visualize stream networks in order to have information on their location and connectivity. Drainage basin analysis for the past decades recognizes spatial development activities and surface drainage networks. The quantitative analysis of morphometric parameters enormously constitutes river basin evaluation. The relationship that exists between basin topography and drainage morphometry is extremely noteworthy in understanding the landform processes, soil physical properties and erosional characteristics. Drainage characteristics of several river 
basins and sub-basins in different parts of the globe have been deliberated using conventional methods. Modern statistical analysis and Geographical Information System (GIS) techniques are increasingly being used for assessing different landscape and morphometric parameters of the drainage basins. A given river channel dynamics can result from a number of processes amidst the pressing environmental conditions such as the geologic composition of the region, volume and rate of Horton's Overland Flows, the available upland loose sediments, inchannel sediment sizes and composition, net sediment transportation within the channel and the consequent depositions on the river floodplain (Zhu et al. 2017).

Cameroon is endowed with plethora of river basins such as the Sanaga River Basin, the Dja River Basin, the Upper Nyong river basin, the Upper Noun River Basin and the Menchum River Basin. These river basins vary in size, shape and the length of their major river. These river basins have many streams that form a dendritic pattern in most cases. Each drainage basin is also characterized by a large river into which small tributaries empty their contents (Mphoweh and Futonge, 2009). The Bamenda-Menchum Drainage Basin is drained by the River Menchum. These river basins form the main watershed of the specific drainage basin. Consequently, the basin' resources such as streams, catchments, waterfalls and flood plains are exploited for socio-economic livelihood. Assessment of watershed characteristics like the nature of the topography, rainfall and temperature and the drainage networks are prerequisite for watershed management. Geographical Information systems (GIS) with Digital Elevation Model are used for the computation of various watershed characteristics effectively and efficiently (Arbind and Madan, 2017). The land use pattern over space and time is a reflection of the complex physical processes acting on the landscape. Assessment of hydrologic influence such as stream competence on the landscape remains appropriate for monitoring watershed change, management and development of BamendaMenchum river basin.

\section{Study Area}

The Bamenda-Menchum drainage basin comprises of varied topographic landscapes ranging from steep, intermediate to flat surfaces. The landscape appears to be developed on a complex geological structure where alternating hard and soft rocks have yielded across the years to differential erosion. The basin has been portraying varied degrees of surface which appear most remarkable in the upland areas of the basin at Abangoh and Ntaghan quarters to the south along the Bamenda escarpment. The high energy hydraulic activity on the escarpment face appears to facilitate landslide, rock fall and soil erosion that increases transport loads on stream channels. Stream channels at Atialah, Ndamukong and Ntefinki quarters of Nkwen experience increase sedimentation that reduce the depth of streams in confined channels exposing the channels to flooding even in minimal rainfall conditions. Streams from the surrounding escarpments of Mendakwe flow in different directions into the River Mezam and River Menchum. This flow breaks up into multitudes of tributaries around low lying summits of the low crystalline plateau. The southern highland slopes present a geological structure of a volcanic chain that portrays an escarpment with dip valleys at the foot of the escarpment that appears underlain by metamorphic basement. The geological structure appears instable and vulnerable to the changing environmental conditions and human development.

The Bamenda-Menchum drainage basin has an estimated surface area of $2840 \mathrm{~km}^{2}$ (Annual Council Reports, 2018). The drainage basin is located between latitude $6^{\circ} 20^{\prime} \mathrm{N}$ and $7^{\circ} 00^{\prime} \mathrm{N}$ of the Equator and between longitude $9^{\circ} 50^{\prime} \mathrm{E}$ and $10^{\circ} 25$ East of the Greenwich Meridian. The drainage basin is bounded to the North and North East by Santa and Bali Sub Divisions, to the North West by Tubah Sub Division and to the South and South-West by the Federal Republic of Nigeria (Figure 1). The study area is classified into two sub basins (Bamenda sub basin and the Lower Bafut-Menchum sub basin). The essence was to show the upstream-downstream linkages of the drainage basin in terms of stream flow direction, flow gravity and fluvial action. The Bamenda-Menchum drainage basin in the North West Region of Cameroon has a monsoonal climatic type. It experiences two marked seasons, namely, the dry season which last for four months (usually Mid November-Mid March) and the rainy season whose duration is eight months (Mid March-Mid November). Rainfall, atmospheric humidity and temperature changes within the drainage basin occur irrespective of the seasons. Such seasonal variation in these climatic elements is visible within the basin. As such the drainage basin is stratified into two climatic boundaries depending on the degree of rainfall and temperature characteristics. These climatic boundaries are based on the altitudinal variation within the drainage basin. The cold and misty climate is experienced in the upland watersheds at elevations between $1500 \mathrm{~m}$ to $2250 \mathrm{~m}$ above sea level. In the same relief zone in the upstream segment of the basin, Bamenda experiences a maximum mean range temperature of $22^{\circ} \mathrm{C}$ and a minimum mean range temperature of $19.5^{\circ} \mathrm{C}$. Also, rainfall in this part of the basin ranges between $2000 \mathrm{~mm}$ to $2560 \mathrm{~mm}$ (Regional Meteorological Service Bamenda, 2018). 


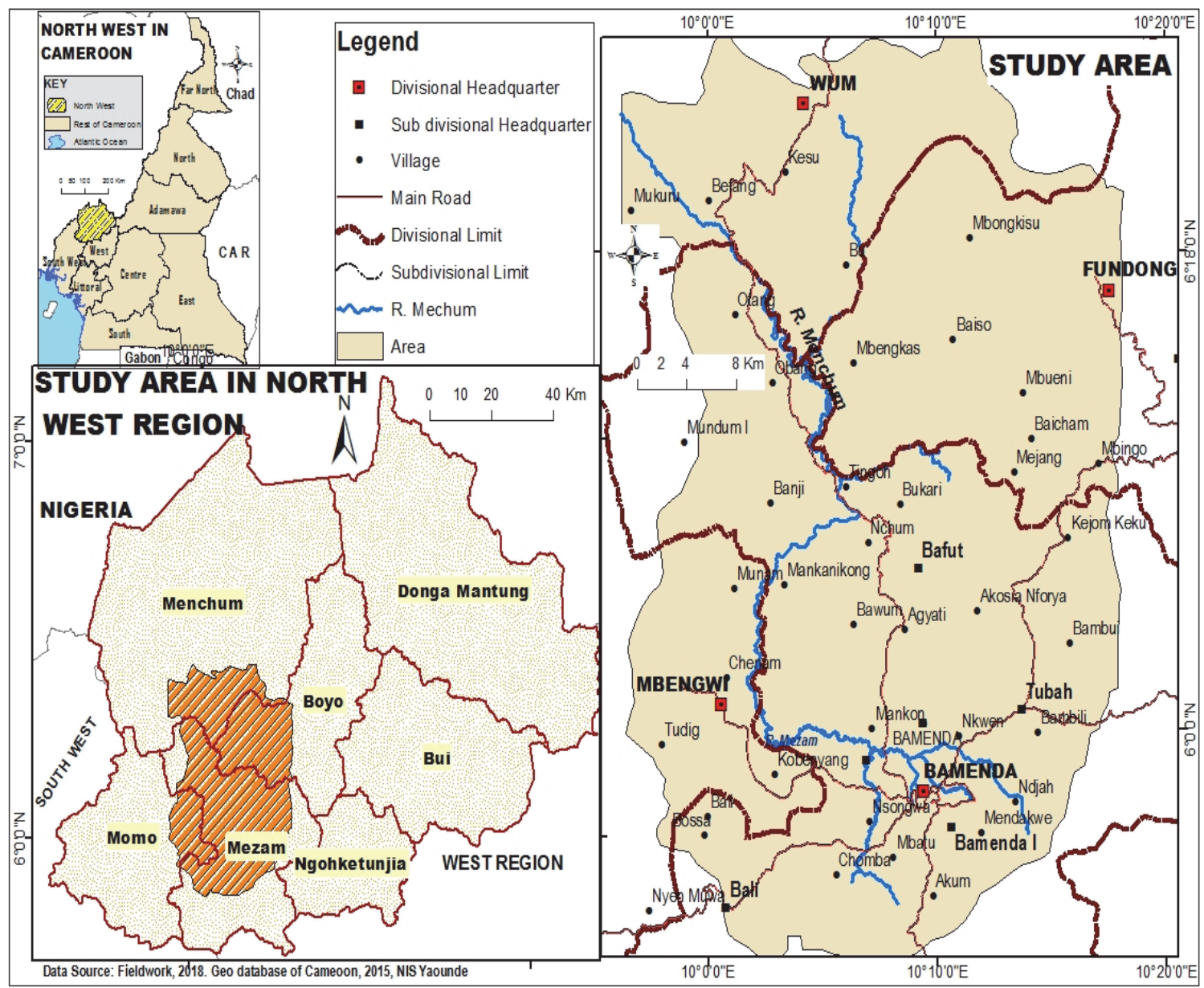

Figure 1. Location of the Bamenda-Menchum Drainage Basin

Source: Google Earth, (2018)

At the lower segment of the basin, with altitudinal range between $500 \mathrm{~m}$ to $900 \mathrm{~m}$ above sea level, the Menchum Valley experiences a maximum mean range temperature of $250 \mathrm{C}$ and a minimum temperature range of $200 \mathrm{C}$. In this part of the basin, rainfall recorded ranges between $2286 \mathrm{~mm}$ to $3048 \mathrm{~mm}$. Figure 2 presents the average monthly rainfall and temperature for the basin.

The maximum rainfall value occurs in the months of August and September (388 and 396mm respectively. Average minimum value is observed in December and January with $11 \mathrm{~mm}$ and $6.9 \mathrm{~mm}$ respectively. During the peak rainy season, the relative humidity exceeds $80 \%$ in August-September and it is lowest in the dry season between JanuaryFebruary with relative range between $25-32 \%$. The monthly and seasonal variation in rainfall conditions determines stream competence and hydraulic activity of the basin. The drainage basin consists of chains of highlands, plateaus plains and valleys that form part of the Western Highlands of Cameroon. In most parts of the basin, the hills fall into deep valleys with steep slippery slopes. The high altitude areas have elevation between $1250 \mathrm{~m}$ to $2250 \mathrm{~m}$ above sea level. The low lying areas lie between $500 \mathrm{~m}-900 \mathrm{~m}$ above sea level. This covers areas such as Tingo, Obang, Bangwe and Modele in the Menchum Valley.

With regard to the drainage of the basin, the Bamenda-Menchum drainage basin is drained by the river Mezam and River Menchum. The river Mezam flows into River Menchum which constitutes the main tributary of the River Katsina in Nigeria. Different patterns of stream flow orientation at different level of elevations exist. The flow patterns show the centripetal and dentritic drainage network. The surrounding highlands form the main watersheds of the basin with numerous tributary streams draining into the main river valleys. The drainage network influences the stream competence and the development prospects of the basin. 


\section{Methodology}

Field observation and questionnaires were employed in different occasions. The essence was to garther first hand information especially on the variation of the landscape, stream flow direction and competence to erode, transport and deposit sediments. Data on topographic variation with regard to elevation were gotten from MEDINO Land Survey Unit and measured and computed by AVL/EBI.JHO. The different topographic units were classified into two sub basins (the Upstream Bamenda sub basin and the Downstream Lower Bafut-Menchum sub basin). Rainfall and temperature were major climatic data used for the study based on the relationship between rainfall and stream competence. Stream flow rate and response to seasonal variation were determined by measuring the flow rates in some first and second order streams. While the discharge of higher order stream of the River Menchum was gotten from Aguili Gauge Station. Questionnaires were used to sample people's opinion of the contribution of stream competence to the development of the drainage basin through sand extraction and agricultural development. Geographic Information Systems (GIS) and Digital Elevation Model (DEM) were used to map out the landscape and to depict landscape variation of the basin. The use of GIS and DEM was to establish the stream flow direction in order to determine the susceptibility of the landscape to stream effects or hydraulic activity. The data were analyzed using the Pearson Product Moment Correlation (r) to show the relationship between stream competence and seasonal variation as well as topographic variation of the basin. The results of the Correlation Coefficient were adjusted using the coefficient of determination $\mathrm{r} 2$. Finally, the reliability of the relationship between seasonality and stream competence was confirmed using the Cronbach's Alpha statistical test. The empirical test was conducted at 0.01 significant level or $99.99 \%$ confident level.

\section{Findings}

\subsection{Landscape and Stream Flow Direction in the Bamenda-Menchum Basin}

This landscape has double geological rock outcrops consisting of trachyte and rhyolites that occupy the escarpment zone. The escarpment therefore shows a high percentage of trachyte and rhyolites that forms the basement steep face sloping landscape. These volcanic rocks have high water holding capacity and positively response to hydraulic actions as well as slope instability. At the foot of the escarpment is the crystalline basement complex consisting of gneiss and granites. The crystalline geological basement covers Bamenda I and Bamenda II that extend to the Mbengwi high plateau. The Southern Highlands of the basin therefore comprise of volcanic geological basement and the crystalline granitic basement that dominates the upstream landscape. The escarpments portray free face slope with altitude generally between $1500 \mathrm{~m}$ and $2200 \mathrm{~m}$ above sea level. The volcanic highland areas have lava plateau with slope gradient greater than $35 \%$. These attributes of the landscape influence the nature of stream flow direction and fluvial activities in the high altitude landscape of the basin. The physical landscape of the high altitude zones show differential results in terms of the altitude and slope gradient (Table 1). These differences explain the response of the landscape to drainage and fluvial activities operating on the landscape.

Table 1. Landscape Characteristics in the Upstream Bamenda Sub Basin

\begin{tabular}{|c|c|c|c|c|c|c|}
\hline \multirow{2}{*}{\multicolumn{2}{|c|}{ Location }} & \multicolumn{5}{|c|}{ Landscape Attributes } \\
\hline & & $\begin{array}{l}\text { Altitude } \\
\text { Range (m) }\end{array}$ & $\begin{array}{l}\text { Slope } \\
\text { gradient }\end{array}$ & Soil texture & Vegetation & \\
\hline $\begin{array}{l}\text { Bamenda } \\
\text { Escarpme }\end{array}$ & & $1500-2200$ & $>35 \%$ & Fine Volcanic & Grassland & \\
\hline Mankon $\mathrm{F}$ & lateau & $1500-2000$ & $20 \%-35 \%$ & Coarse basaltic & $\begin{array}{l}\text { Grassland } \& \\
\text { montane forest }\end{array}$ & semi \\
\hline Nkwen & Plateau & $1200-1500$ & $14 \%-28 \%$ & Coarse granitic & $\begin{array}{l}\text { Grassland } \\
\text { montane forest }\end{array}$ & semi \\
\hline $\begin{array}{l}\text { Lower } \\
\text { Menchum }\end{array}$ & Bafut- & $400-900$ & $<10 \%$ & $\begin{array}{l}\text { Colluvio-Alluvial } \\
\text { Deposits }\end{array}$ & Swamp Gallery & \\
\hline
\end{tabular}

Source: Adapted from AVL/EBI/JHO, (1986) and Modified by Authors, (2018)

The southern highlands of this basin constitute the haven for tributary. The tributaries of this river basin radiate from the surrounding volcanic and granitic basement complexes and drain into the Rivers Mezam. The availability 
of these tributaries in the southern highlands of Bamenda explains the high water holding ability of volcanic landscape and the granitic basement. The nature of drainage condition (well drained or poorly drained) in the different geological structures of the Bamenda sub basin is explained by the frequency, drainage density and stream flow direction in which geological structure or the nature of the topography appear to exert great influence in the stream network distribution of the basin.

The free face slope along the Bamenda-Tubah landscape shows numerous waterfalls indicating that the landscape has failed to maintain a constant and continuous gradient. The escarpment therefore obstructs the free flow of streams on the landscape. Consequently, most of the streams disappear and reappear at the foot of the escarpment especially at Sisia, Abangoh and Ntaghan as springs. The spring sources flow on the surface constituting streams of different order depending on the regular and seasonal flow pattern of the streams. The southern volcanic highlands of the basin portray high water holding capacity especially during the rainy season. The volcanic aquifers absorb and hold water such that this zone remains the main watershed to the downstream communities. This equally explains why even in the dry season, water sometimes seep out of the escarpment indicating the potential holding capacity. Nevertheless, most streams are highly vulnerable and liable to seasonality effects and climatic oscillations so much so that some streams and springs cease to flow while other substantially reduce in volume. The drainage network of the basin is presented in figure 2 .

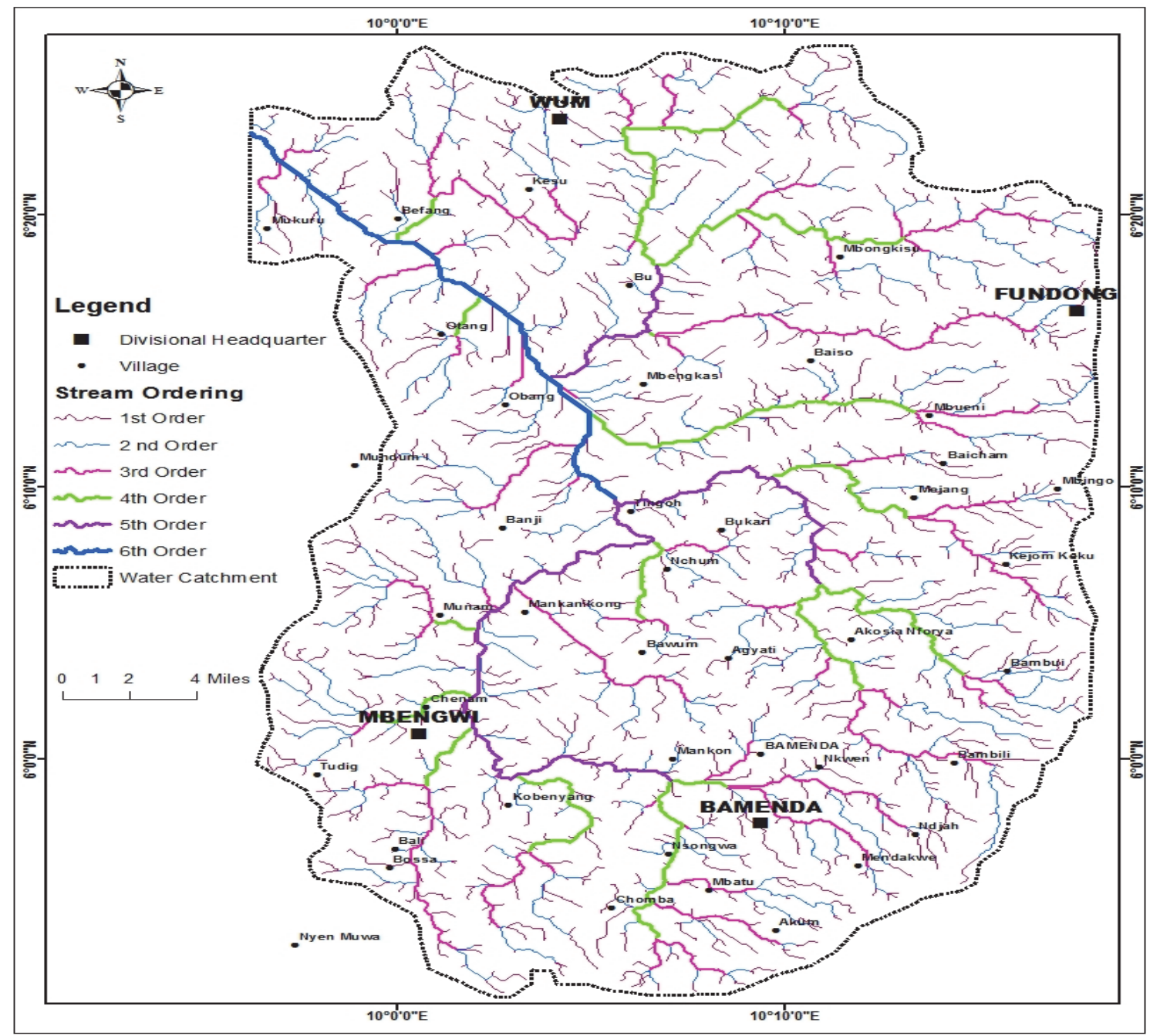

Figure 2. Stream Network of the Bamenda-Menchum Basin

Source: GIS, (2017)

The streams categorization was based on the seasonal availability and reliable of flow pattern. Consequently, field analysis identified streams that cease to flow completely during the dry season (ephemeral streams), streams that 
reduces drastically in the volume of flow (intermittent streams) and streams that shows a slight decrease in volume of flow (perennial stream). However, the flow direction of streams differs between the volcanic escarpment of Bamenda and the crystalline basement that extends from the foot of the Bamenda escarpment. Consequently, first and second order streams in the Bamenda escarpment flow in no preferred direction. Four main flow directions (North-South, East-West, South East-North West and North East-South West) were established to determine the flow orientation of streams in the sub basin (Table 2).

Table 2. No dominant stream flow direction in the volcanic escarpment of Bamenda Sub Basin

\begin{tabular}{lllll}
\hline Stream Order & \multicolumn{3}{l}{ Stream Flow Direction } \\
\cline { 2 - 5 } & SE-NW & NE-SW & E-W & N-S \\
First Order & 95 & 83 & 87 & 81 \\
Second Order & 42 & 39 & 26 & 36 \\
Total & 137 & 122 & 113 & 117 \\
Percentages & 28.01 & 24.94 & 23.10 & 23.95 \\
\hline
\end{tabular}

Source: GIS Mapping and Analysis, (2017)

The first and second order streams were used for analysis of flow direction in the volcanic escarpment because these streams exploit the summit areas and contribute to the high order segments downstream. The absence of dominant flow direction indicates that most of these stream segments (1st and 2nd Orders) that exploits the upstream do not have defined fracture lines. This however suggests that the geological structure of the volcanic landscape does not exert significant influence on stream flow direction. The streams do not have preferred flow direction as the steep escarpment present homogenous basement complex of volcanic origin (trachytes and rhyolites) that allows maximum infiltration and aquifer water holding capacity. The flow direction of streams appeared in adendritic drainage pattern suggesting that streams failed to respect the underlying geological structural control but response positively to the steep nature of the escarpment. Findings show that $28.01 \%$ streams flow SE-NW direction while $24.94 \%$ of streams flow from NE-SW direction. $23.10 \%$ of streams flow from E-W direction and $23.95 \%$ flow from N-S direction. The flow pattern and direction of flow is explained by the near absence of defined and confined fractured lines on the escarpment. The flow pattern of the streams not guided by geological structural control explains the non linear relationship between stream flow direction and occurrence of well established fractures.

The results revealed that the absence of dominant stream flow direction indicates high drainage density and high water holding capacity in the volcanic escarpments or landscape of the upper basin. The streams therefore flow relatively in all direction so much so that the spider-web of stream network produced a dendritic drainage pattern. Field observation shows that second order streams provide more defined fractures or channels for stream flow than first order streams. The higher order streams were used to analyze the flow direction at the foot of the escarpment. The streams network stretched from East to West, North to South, North East-South West and South East-North West directions but appeared more dominant in some directions (Table 3). The valleys appeared as fractures and cracks that are exploited by higher order streams (3rd, 4th and 5th order streams). These stream orders have different channel width and depth such that the streams are confined to specific channels. The relationship between streams and fractures or depression in the crystalline basement appeared perfect and strong as the geological structure strictly controls the flow direction of streams. Findings equally established that some of the wide depressions with second order streams especially at Sisia, Azeri and Mbatu appeared as dry valleys during the peak dry season.

Table 3. Dominant stream flow direction in the Crystalline Basement at the Foot of the Bamenda Escarpment

\begin{tabular}{lllll}
\hline Stream Order & \multicolumn{4}{l}{ Stream Flow Direction } \\
\cline { 2 - 5 } & SE-NW & NE-SW & E-W & N-S \\
Third Order & 43 & 38 & 15 & 18 \\
Fourth Order & 17 & 5 & 2 & 3 \\
\hline
\end{tabular}




\begin{tabular}{lllll}
\hline Fifth Order & 3 & 1 & 0 & 1 \\
Total & 63 & 44 & 17 & 22 \\
Percentages & 43.15 & 30.14 & 11.64 & 15.07 \\
\hline
\end{tabular}

Source: GIS Mapping and Analysis, (2017)

Finding revealed two controlled stream flow direction that is the SE-NW and NE-SW (Figure 3). The South WestNorth West direction accounted for about $43.15 \%$ of stream flow while the North East-South West direction controls over $30.14 \%$ of the stream network. The least preferred directions were the East-West and North-South with $11.64 \%$ and $15.07 \%$ respectively. The results therefore show that there is a dominant stream flow direction. The analysis of streams in this area was guided by the availability of streams, stream orders, channel length and the direction of flow. Streams tend to exploit the crystalline basement along lines of weakness thereby necessitating the flow of streams over long distance before meandering except in areas of human interference within the stream courses.

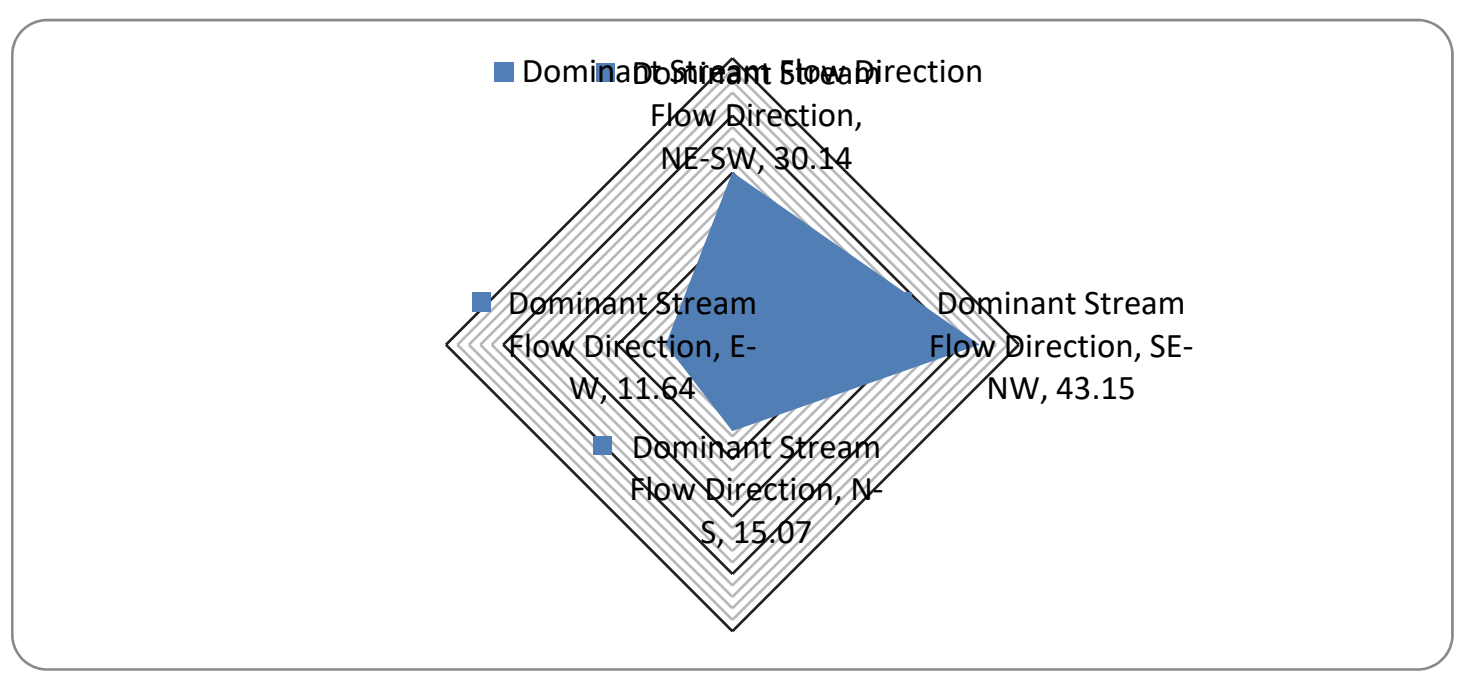

Figure 3. Dominant Stream Flow Direction on the Bamenda Crystalline Basement

Source: GIS Analysis, (2017)

The relationship between stream order and geological structural control indicates that the higher the stream orders the higher the ability of the streams to flow along joints or fractured lines thereby resulting in high stream competence. This implies that 4th order streams have more defined and confined channels than 3rd Order streams. Consequently, 4th order streams have high competence to erode, transport and deposit materials than 3rd order streams. Also, the dominant direction of flow justified that geological structure with fractures, valleys and lines of weakness particularly in the crystalline basement of Bamenda exert significant control on stream flow such that streams follow these channels or fractured lines. Hence, the stream frequency and drainage density in these crystalline rocks shows unevenness on the landscape. Based on the analysis of stream flow direction, the results show that the areas South East-North West and North East-South West appeared to have more streams of higher order and high drainage density. Some of the areas such as Mulang, Musang and Below Foncha are poorly drained. The poorly drained areas indicate the presence of higher order streams (4th Order) that meander at short distances liable to the development of marshy and swampy landscape. Most part of the crystalline rocks appeared to be well drained such as Small Mankon and Atua-Azei as streams are confined enough to channels that outcrop and direct stream flow into the River Mezam and River Menchum. The results equally revealed many higher order streams (3rd, 4th and 5th) in the South and South Western slopes than the North and North Eastern slopes of the landscape. This implies that fewer order streams are observed at Futru and Atialah than at Bayele, Mulang, Old Town and Atu-Azire. 


\subsubsection{Landscape and Stream Flow Direction in the Lower Bafut-Menchum Basin}

The low altitude sedimentary basin equally known as the Menchum Valley falls between $400 \mathrm{~m}$ to $800 \mathrm{~m}$ above sea level. This sedimentary basin covers the Lower Bafut-Menchum basin and extends to Tingo, Mbakong, Mile 34, Obang, Aguili and Bangwe. This area comprises of peneplain, accumulation of sediments from the surrounding highlands of Bamenda, Tubah, Wum, Oshie and Fundong landscapes. The accumulation of sediments forms Oxbow lakes that facilitate stream meandering along the plain. The slopes are relatively flat ranging between $2 \%-5 \%$ with the development of flood plain and swampy surfaces. The parent material is from alluvial deposits and the soil type mostly developed in this area is the alluvial soils. The Lower Bafut-Menchum basin forms the discharge zone in which the tributaries of the highlands drain into the River Menchum which is the main river of the basin. The low lying areas of the Lower Bafut-Menchum basin present uniform and homogenous alluvial deposits that accumulate to form the sedimentary basin of similar resistance to denudational processes. The flat nature of the landscape with extensive flood plain allows 4th, 5th and 6th Order streams to flow in all directions. The first, second and third order streams have been excluded for drainage analysis in this part of the basin. This is explained by the fact that these lower order streams have been lost to the higher order streams as the streams flow from the surrounding highlands into the Lower Bafut-Menchum Basin. The landscape therefore revealed a dendritic drainage pattern such that the stream pattern does not exhibit dominant flow direction. Various stream orders therefore have equal chances of flow directions (North, South, East and West) of the basin.

The probability of streams to flow in all direction provides a random distribution of streams. This equally justified that the dominant controlling factor of stream flow direction in the sedimentary basin of the Lower BafutMenchum is the nature of the topography. The underlying geological structure does not exert significant role in the flow direction of streams. Nevertheless, the higher stream orders (4th, 5th and 6th) appeared to flow in confined channels exploiting the lines of weakness. This however holds that the flow of streams is directed by the channels or fractured lines especially streams that flow from $\mathrm{Bu}$, Mbengkas and Mundum into the River Menchum producing distinctive channel flow. The downstream basin therefore revealed fewer streams of fourth, fifth and sixth orders in the respective flow directions. The reduced number of higher order streams justified the convergence of lower order streams so much so that the number of 4th order streams is more than 5 th order streams while 5th order streams are more than 6th order streams in all flow directions. The fewer higher order streams indicate low stream frequency and drainage density and a reduce stream competence. The drainage characteristics of the Lower Bafut-Menchum revealed a poorly drained landscape especially due to the low-lying nature of the surface that facilitates the development of swamps and marshy surfaces liable to flooding.

\subsubsection{Assessment of Seasonality and Stream Competence in the Bamenda-Menchum Basin}

Streams competence of this drainage basin varies with the nature of the topography and seasonal variation. The Bamenda topographic landscape comprises of volcanic escarpment and crystalline basement in which streams outcrop and flow into the River Mezam in different directions. During the rainy season, these highlands provide for lower stream orders (1st and 2nd Order streams). The first order streams do not have the competence to sufficiently erode or transport materials from the surrounding highland areas. The Bamenda escarpment shows a natural steep face with volcanic basement that have high water absorbing ability. These rock types have several joints or cracks such that there is maximum infiltration capacity. The saturated nature of the geological structure characterized by fractures allows groundwater seepage such that the first order streams reappear at the foot of the escarpment. These streams that reappear at the base of the escarpment tend to flow in some underdeveloped stream channels carrying along few soils and rock debris. At this point, the ability of the streams to erode and transport materials is low even at the peak of the rainy season. Consequently, abrasion, attrition and hydraulic processes remain low both in the rainy and dry season. This is explained by the fact that, the steep escarpment zone does not provide any dominant stream flow direction thereby reducing the chances of merging to form higher order streams.

The situation of stream competence to erode and transport materials equally varies across the escarpment zone. The variation in hydraulic activity is attributed to the fact that some areas such as Ntaghan and Sisia III, Sisia IV and Sisia V have several waterfall points than Abangoh. The waterfall zones experience rapid downfall of streams provoked by the presence of steep facing slope. The summit of the waterfall does not experience significant material lost but significant removal and transportation of materials is observed at the foot of the escarpment where the fall exert pressure on the landscape thereby necessitating soil and gully erosion. Large particles of rocks and sand are eroded and transportation at high velocity due to the increase hydraulic activity at the waterfall zones. Findings revealed that the high hydraulic activity correspond to the increasing volume of waterfall. However, well define channels exist in areas of high hydraulic activity especially at Ntaghan and Sisia quarters of Mendkwe and Nkwen respectively. 
However, the hydraulic competence of the waterfall and streams in the Bamenda escarpment equally vary with seasons. During the rainy season, waterfalls along the escarpment increase in volume out-cropping most parts of the escarpment. The increase in volume of falls indicates increase stream ability to erode and transport materials from the high escarpment zone to the foot of the escarpment. The increase in streams competence is justified by increase in rainfall condition especially between July and September where monthly rainfall falls between $350 \mathrm{~mm}$ and $450 \mathrm{~mm}$. The monthly rainfall total is sufficient to saturate the volcanic escarpment such that springs and streams contribute significantly to erosion and transportation of materials from the escarpment slope. The highland and escarpment face increases the flow gravity of streams which increases the stream competence to erode and transport materials. The high stream energy reduces as the stream flow through the gentle slope at the escarpment base of the crystalline basement complex. Findings revealed that most of the eroded sediments or materials are deposited along stream channels of the crystalline basement. This is attributed to the gentle nature of the slope as well as the accumulation of infrastructural and domestic waste materials on stream channels given that the crystalline basement is the urbanized Bamenda city sphere. Nevertheless, efficient erosion and transportation of materials is pronounced only at the vicinity of waterfalls or in areas of higher order streams (3rd, 4th and 5th).

At the foot of the Bamenda escarpment that constitutes the geological crystalline basement complex differential erosion, transportation and deposition of materials occurs. This geological basement spans across Nkwen, Mankon and Bali-Mbengwi axis with shallow wide valleys that are drained by streams of higher orders. Findings revealed that during the rainy season, most streams channels at Old Town, Bayelle, Atialah, Futru, Ndamukong and Ngongham experience channel scrapping and widening as a result of increase hydraulic and stream competence in the sub basin. Also, channel deepening and development of gullies are commonplace in this sub basin. This explains the increase stream ability to erode and transport materials of various sizes. The crystalline basement revealed increase concentration of fluvial activities given that the basement complex has a gentle-sloping landscape that lies immediately at the foot of the escarpment. The high velocity of waterfalls that merge to form higher order streams contribute significantly to the hydraulic action at Nkwen and Mankon of the sub basin. Findings equally show that the ability of the streams to transport materials drops in some channels of Nkwen and Mankon. The drop in the rate of transportation of debris in confined channels is explained by the fact that some of these streams run through urban wetlands of Bayelle, Futru, Musang, Mulang and Ngongham such that the flow velocity of the streams is reduced. This reduction of the flow velocity indicates that the streams cannot longer transport sufficient loads enhancing sediments accumulation along confined channels. This result in increase sedimentation of eroded and transported loads that appeared unable to reach the intended flow direction (Lower Bafut-Menchum Basin).

During the dry season (November-March), the pattern of stream competence drops significantly. During this period the basin relies on the aquifers in the escarpment to release water since the volcanic escarpment has high potentials to hold excess water during the rainy season. The stream flow equally depends on the wetlands that act as sponge to hold water during hydrological excess and release water during periods of deficit. These two water sources are not sufficient enough to ensure increase hydraulic activities within the sub basin. This is justified by the fact that the escarpment on the one hand has been experiencing rapid urbanization such that the aquifers are considerably affected and exposed by man induced activities. On the other hand, the wetlands are increasing being reclaimed so much so that most wetlands at Bayelle, Futru and Ndamukong have failed to achieve the sponge role in the sub basin. Such conditions indicate that streams flow along channels drastically reduces the competence to erode and transport loads. Consequently, the stream ability to deposit materials or sediments along channels increases significantly during the dry season where maximum water levels and stream current in channels drops. Figure 8a and $8 \mathrm{~b}$ show the seasonality effect of some sampled 3rd and 4th order streams measured in the Bamenda-Mbengwi sub basin.

The results show that Mulang stream is highly vulnerable to seasonal changes. This is shown by the wide gap that exists between the maximum level of water in August $(6 \mathrm{~m})$ and maximum level of in January $(1 \mathrm{~m})$ in the stream channel. This is followed by Ngeng stream with maximum and minimum heights of $4 \mathrm{~m}$ in August and $0.5 \mathrm{~m}$ in January. The reason for such drastic fluctuation between maximum and minimum water levels is accounted by the fact that some tributary streams (1st Order and 2nd Order streams) which supply water to the Mulang stream cease to flow during this period. Also, the increasing reclamation of wetlands which are main sources of stream flow in this area explains the drastic decline of water level in January.

Seasonality brings about changes in rainfall and temperature conditions in the drainage basin. The different months of the years are grouped into rainy season and dray season. A shift in the rainy days and sunshine days in each month definitely affects the availability of water held in aquifers as well as volume of water discharge in stream channels. Consequently, rainfall and temperature of the basin plays important role in determining stream 
competence of the sub basin in particular and the drainage basin in general. The results show differential stream competence (low, moderate and high stream competence) that depends on the average monthly rainfall amount (Figure 4). The results revealed that hydraulic activities remain low during the dry season that runs from November to February. This is as a result of significant drop in the rainfall recorded in the drainage basin at this time. Consequently, most streams are liable to reduce in volume or cease to flow completely. The results therefore shows a direct relationship between rainfall conditions and hydraulic or stream competence. Hence, the decline in rainfall condition reduces stream energy and ability to erode and transport loads. In another dimension, the increase in rainfall conditions increases the stream energy to erode and transport loads.

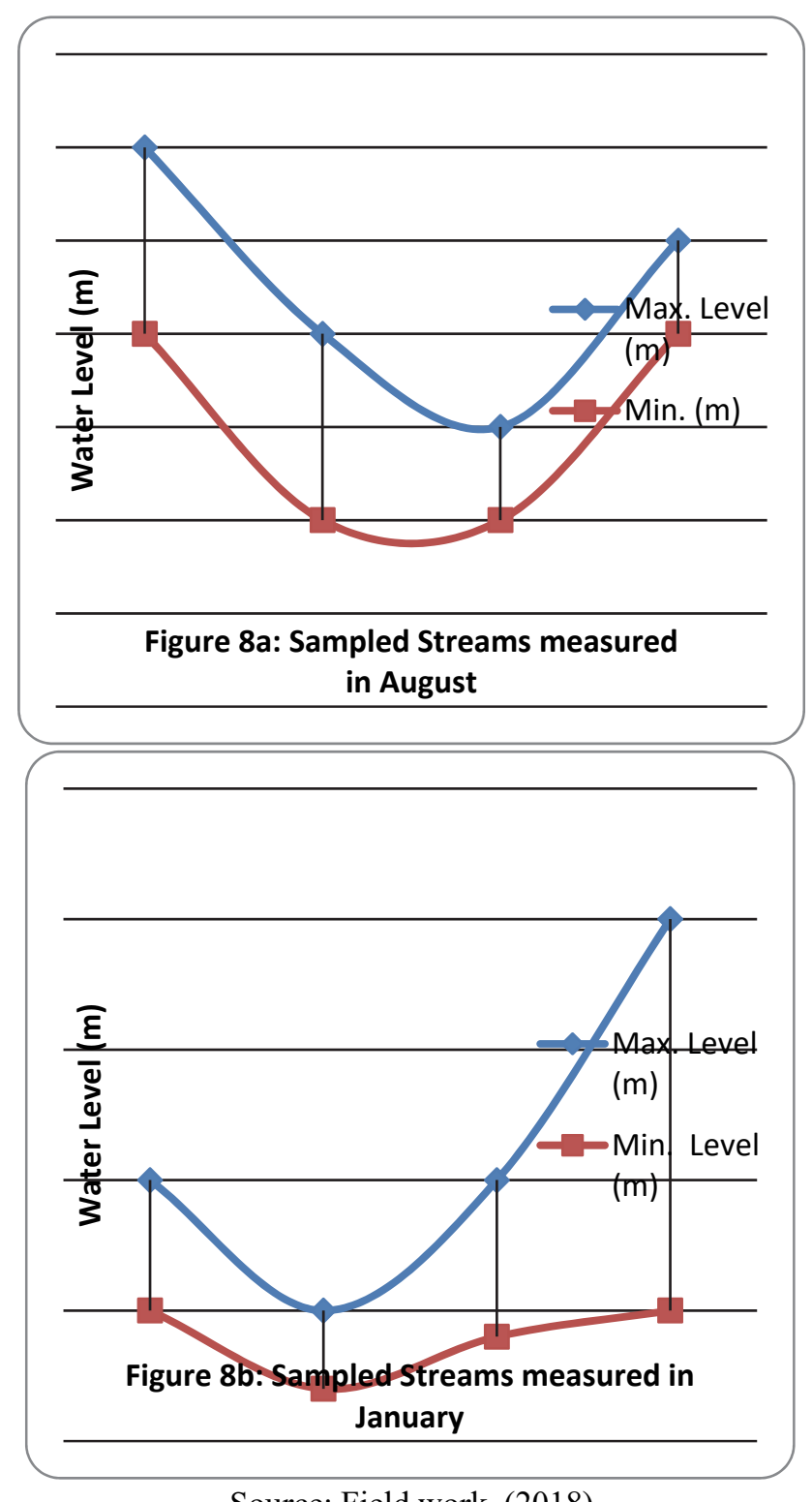

Source: Field work, (2018) 


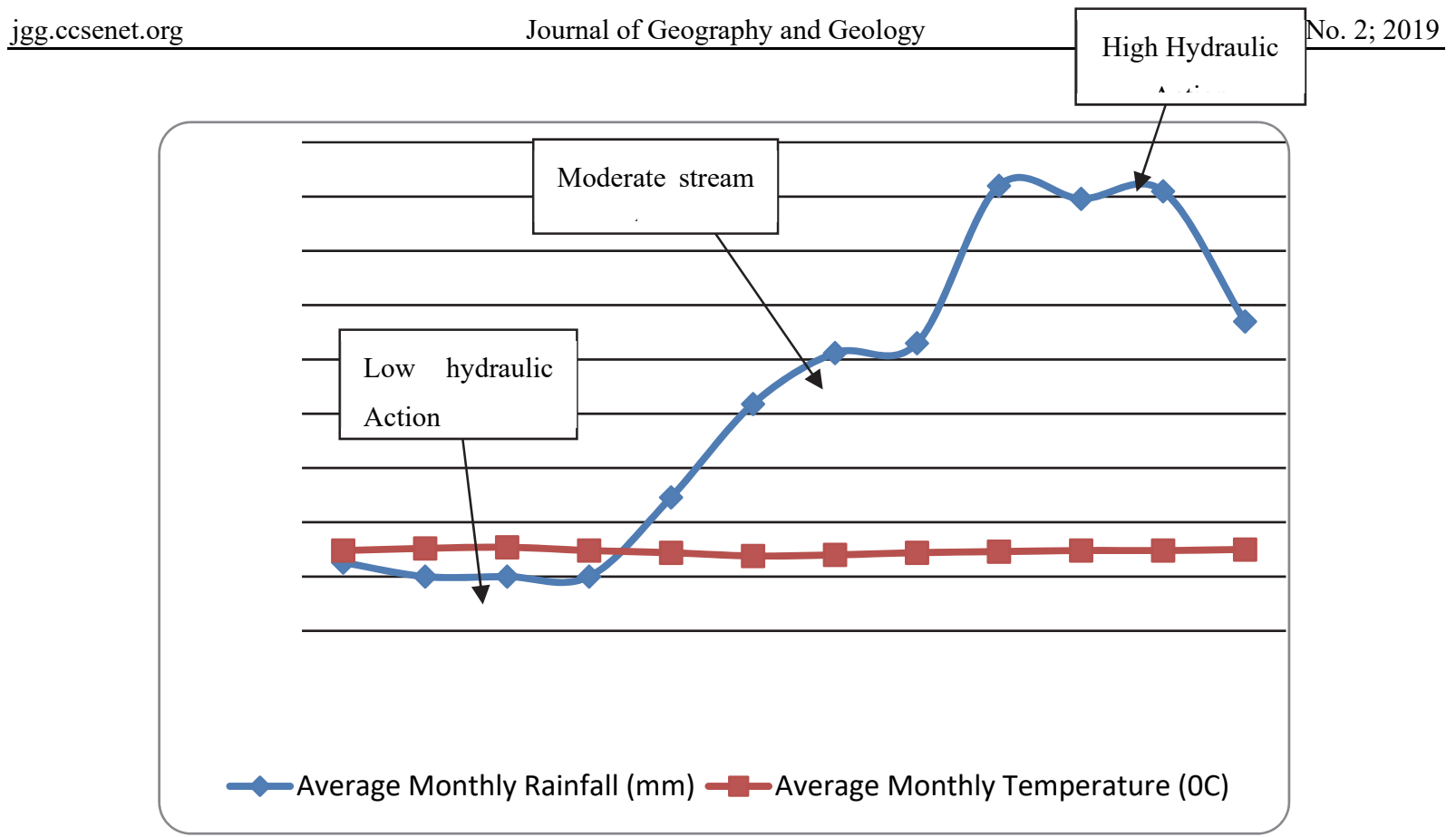

Figure 4. Average monthly rainfall and temperature

Source: Bamenda Meteorological Station (2018)

Finding revealed that increase rainfall increase surface runoff that result in erosion of the land surface so much so that the eroded and transported materials (gravels, sand and soil particles) are deposited on the stream channels. The deposition of materials occurs when the stream energy drops and the stream cannot longer transport loads of larger sizes. The high hydraulic activities correspond to the peak rainy months of July, August and September. The transition period (March-June) that separates the peak rainy period from the peak dry periods indicates moderate hydraulic actions. The landscape of this sub basin is characterized by several depressions and shallow valleys that are exploited by ephemeral, intermittent and perennial streams. The ephemeral streams have a reduce effect of eroding and transporting loads in confined stream channels. Most of the channels have laminar stream flows close to the surface with average channel width of $1.33 \mathrm{~m}$ (Table 4). The results revealed that ephemeral streams vary in flow rate with seasons. At Sisia during the rainy season, a stream depth of $0.78 \mathrm{~m}$ was measured to flow over $100 \mathrm{~m}$ in 60 seconds. This shows that the measured stream covers $1 \mathrm{~m}$ in $0.6 \mathrm{~s}$. At Abangoh, the stream depth of $0.60 \mathrm{~m}$ covered $100 \mathrm{~m}$ in 90 seconds.

Table 4. Seasonal Measurement of Ephemeral Streams in the Bamenda-Mbengwi Sub Basin

\begin{tabular}{llllllll}
\hline Quarters & \multicolumn{3}{l}{ Peak Rainy Season Situation (Aug-Sept) } & \multicolumn{3}{l}{ Peak Dry Season Situation (Dec-Jan) } \\
\cline { 2 - 7 } & $\begin{array}{l}\text { Channel } \\
\text { width }(\mathrm{m})\end{array}$ & $\begin{array}{l}\text { Water } \\
(\mathrm{m})\end{array}$ & $\begin{array}{l}\text { Flow } \\
(\mathrm{m} / \mathrm{s})\end{array}$ & rate & $\begin{array}{l}\text { Channel } \\
\text { width }(\mathrm{m})\end{array}$ & $\begin{array}{l}\text { Water } \\
\text { depth }(\mathrm{m})\end{array}$ & $\begin{array}{l}\text { Flow rate } \\
(\mathrm{m} / \mathrm{s})\end{array}$ \\
Sisia I & 2 & 0.78 & $100 / 60$ & 2 & 0.35 & $100 / 150$ \\
Ntaghan & 1 & 0.45 & $100 / 80$ & 1 & 0.20 & $100 / 210$ \\
Abangoh & 1 & 0.60 & $100 / 90$ & 1 & 0.26 & $100 / 240$ \\
Average & 1.33 & 0.57 & $1 / 1.30$ & 1.33 & 0.27 & \\
\hline
\end{tabular}

Source: Field work, (2018).

However, the stream at Ntaghan had a much lower depth of $0.45 \mathrm{~m}$ but cover the same distance $(100 \mathrm{~m})$ at a reduce time compared to the stream at Abangoh. This is explained by the steep gradient of the channel at Ntaghan that facilitates a relative higher flow of stream. During the dry season, water depths dropped considerably in all the sampled streams such that the streams cover the same distance (100) at a longer time frame. The inability of ephemeral streams to erode or transport loads has resulted in accumulation of small boulder stones along the stream channels. The seasonality effect and climatic oscillation experienced in the high altitude volcanic landscape 
presents spatial vulnerability in terms of stream and spring flow. Findings revealed that a total of 47 streams/springs were observed at the escarpment zone of the sub basin. Consequently, about $15.66 \%$ of the streams/springs at the volcanic escarpment were observed.

The results show that about $52.78 \%$ of the streams/spring observed at Mendakwe ceased to flow during the peak dry season (December to February). 16.11\% of the streams/spring reduced slightly in the volume of flow while $31.11 \%$ of the streams/springs reduced drastically in volume. The high value of streams that ceased to flow during the peak dry season is explained by the fact that the volcanic escarpment has volcanic basement outcrop that has high water holding capacity but equally remains sensitive to drier conditions such that excess water is lost in the geological structure during this period. Equally, the tributary streams in this sub basin are increasingly being exposed by settlement construction and farming activities that expose the fragile landscape to intense sunlight during the harsh dry season. However, the streams that ceased to flow during this period are mainly first order streams. These streams observed depend on the aquifer potential to release water and so, do not have supplementary water sources to flow during the peak dry season. The streams therefore remain ephemeral and highly vulnerable to dry seasonal conditions. However, significant changes in stream flow were observed in the crystalline granitic basement at the foot of the escarpment. The results of streams response to dry season effect show that $31.43 \%$ of streams in the geological crystalline basement of Bamenda ceased to flow during the peak dry season. Streams in this sub basin shows varied response to seasonality conditions such that streams that flow across Down Town-Old Town to the urbanizing landscape are highly affected.

This is shown by the high percentage (50\%) of streams that do not flow during the peak dry season. Equally, Down Town-Old Town lies directly at the base of the escarpment and the flow of streams depends on the ability of the escarpment to release water to constitute first order streams. The first order streams easily dry up so much so that majority of streams in the area cease to flow. Ndamukong present a less vulnerable stream flow situation as only $12.5 \%$ of the streams cease to flow during the dry season; This is attributed to the fact that most of the first and second order streams in the sub basin that flow in this direction increase in volume such that the peak dry season condition cause streams to reduce drastically in volume of flow (62.5\%). In a similar manner about $16.67 \%$ of streams that flow at Atialah cease to flow during the peak dry season. $33.33 \%$ of streams reduce slightly while $50 \%$ of streams reduce drastically in volume of flow. This drastic reduction in the volume of flow is equally explained by the disappearance of some tributary streams in the dry season that usually contribute to flow during the rainy. For the sub basin, the results revealed that about $25.12 \%$ of streams reduce slightly in volume while $43.45 \%$ of streams reduced drastically in volume of flow during the peak dry season. The intermittent streams that reduce drastically in volume during the dry season slightly increase the wearing of stream banks or channels during intense rainstorms causing rock particles, weathered materials and infrastructural wastes to be eroded, transported and deposited in different areas of the channels. The intermittent streams have an average channel width of $3 \mathrm{~m}$ characterized by stones, gravel and boulders of larger sizes indicating a much higher water level in stream channels. Perennial streams reduce slightly in volume of flow and are responsible for the large channel widening, deepening and scrapping with considerable transportation of materials. Deposition of materials remains high in areas of reduce friction from braiding activity or where the channel gradient and vegetal cover restrict free movement of sediments along stream channels.

\subsubsection{Seasonality and Stream Competence in the Lower Bafut-Menchum Basin}

The Lower Bafut-Menchum sub basin is topographically flat and drained by the River Menchum. The sub basin therefore is a discharge zone that receives transported loads and water from the surrounding highlands. Findings revealed that the basin receives higher order streams $\left(3^{\text {rd }}, 4^{\text {th }}\right.$ and $\left.5^{\text {th }}\right)$ that flow into the River Menchum. The immediate surrounding highlands of the sub basin equally allow $1^{\text {st }}$ and $2^{\text {nd }}$ order streams to flow and link up with the $6^{\text {th }}$ order stream (River Menchum). The River Menchum which is the $6^{\text {th }}$ order stream response to seasonality effect in terms of discharge and the river competence to erode, transport and deposit materials along river channel. The discharge of the River Menchum shows a significant difference between the rainy season and the dry season (Figure 5). The simulated measurement of the river Menchum shows high discharge values over that measured by ORSTOM in 1980 at Aguili Guage Station. Independent results revealed that the rainy season presents a much higher discharge or water level than the dry season. The water levels in both seasons show high fluctuation in water levels between the dry season and the rainy season of the sub basin. The maximum water level in January was $1.7 \mathrm{~m}$ high and the value dropped to $1.5 \mathrm{~m}$ and $1 \mathrm{~m}$ in February and March respectively. 


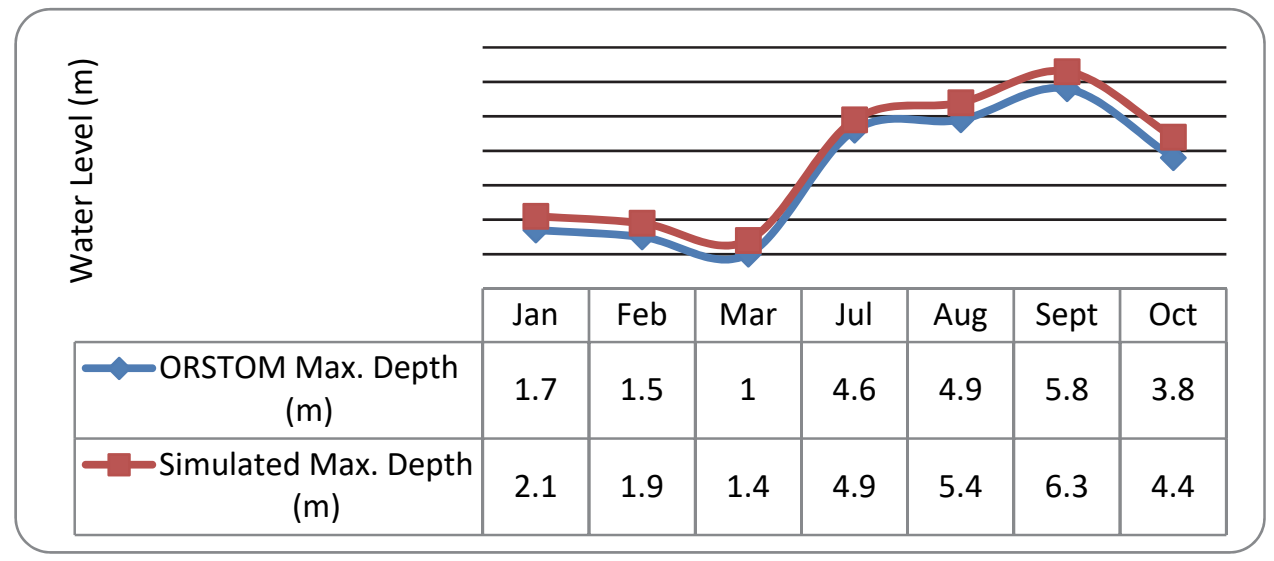

Figure 5. Maximum Seasonal Water of the River Menchum

Source: ORSTOM (1980) and Simulated (2018)

The depth of the river increased drastically during the rainy season. The water depth showed a progressive trend in July, August and September of about $4.6 \mathrm{~m}, 4.9 \mathrm{~m}$ and $5.8 \mathrm{~m}$ respectively. The increase in the water level is accounted for by the corresponding increase in rainfall of the drainage basin. The approach of the dry season was signaled by the declining water level that dropped to about $3.8 \mathrm{~m}$. The corresponding trend or pattern of increase and decrease in the water level with regard to seasonal changes is consistent between the ORSTOM maximum levels and simulated maximum levels. The increase simulated water levels both in the dry and rainy season is explained by the urbanization effect in the upstream sub basins. The rapid urbanization accelerates increase runoff and floods that is discharge into river channels thereby increasing water depths and the flow rates downstream of the Lower Bafut-Menchum sub basin. As of 1980, when the ORSTOM statistics on the River Menchum water depth were taken, much of the upstream landscapes were not urbanized and thus, remained natural to enhance infiltration giving a reduced water level in the river channels.

The hydraulic activity and the river competence strictly depend on the water levels and flow velocity of the streams and rivers which are a function of rainfall or seasonality scenario of the drainage basin. The results therefore revealed that the Lower Bafut-Menchum sub basin has been experiencing increasing erosion, transportation and deposition of materials. Erosion and transportation are more dominant at Tingoh gentle slopes where the river energy is accelerated. At Tingo the frictional effect of the river is visible with hydraulic action, abrasion and attrition processes occurring at great intensity. Much of the heavy rock materials transported from the upper Bafut landscape hit against each other at Tingoh as the river channel shows high degree of roughness as a result of heavy rocks accumulation. The channel is equally widened by the continuous hydraulic activities in the area. Rounded and smooth rock surfaces are visible during the dry season when the water level drops indicating a previously high water level, high river gravity and frictional effect that resulted in rock break down in the river channel. The frictional effect is responsible for the fine sandy materials deposited in the river channel. From the Tingoh, the channel slope appeared flat especially at Obang, Otang, and Bangwe. The river energy in these areas drops as the river flows and meanders across the flood plain of the Menchum basin. The decline in the river velocity indicates that the river competence to erode and transport materials has been reduced. Consequently, the transported sandy materials eroded from channels walls and other surfaces are deposited along the river channel as sand. Therefore, the Lower Bafut-Menchum basin is essentially recognized for the increasing deposition and sedimentation processes in the sub basin.

\subsection{Conclusion and Recommendations}

The physical landscape is characterized by complex topographic configuration that has remained entirely exposed to climatic changes and man induced activities. The complex basement of the Bamenda-Menchum basin has yielded differential geological structures which are exploited by streams. Volcanic and crystalline landscape response differently to denudational processes replicated on the fluvial and stream competence to erode, transport and deposit materials. The volcanic escarpment of Bamenda presents no dominant flow direction of streams indicating that the steep face of the escarpment or the topography is the dominant control factor. The steep face accelerates high hydraulic activity and increase flow gravity of streams. The underlain crystalline basement at the foot of the escarpment characterized by deep wide valleys with defined channels revealed a dominant stream flow 
direction. The valleys or fractured lines guide streams flow such that the geological structure is the main controlling factor. Seasonal variation orchestrated by marked changes in rainfall conditions of the basin influence stream ability to erode, transport and deposit material. While the stream energy and flow gravity is high in the rainy season, the competence remains low in the dry season. Consequently, about $76.7 \%$ of stream competence of the basin is explained by the combine effects of topographic variation and seasonality. The hydraulic activity equally provides prospects for sand extraction, quarry and agricultural activity especially in the Lower Bafut-Menchum basin. This study therefore recommends the protection of the fragile volcanic escarpment from human encroachment, proper channel maintenance and modern techniques of sand extraction through the use of machines, construction of a sand factory to encourage sand business and the development of the agrarian basin by making use of the alluvial deposits of the drainage basin.

\section{Reference}

Adegoke, K. M., \& Bulus, L. G. (2015): Hydrological and morphometric analysis of Upper Yedzam catchment of Mubi in Adamawa State, Nigeria, using GIS. World Environment, 5(2), 63-69.

Arbind, K. V., \& Madan, K. Jha (2017). Extraction of Watershed Characteristics using GIS Model and Digital Elevation; International Journal of Engineering Science Invention ISSN (Online): 2319 - 6734, ISSN (Print): 2319-6726PP. 01-06.

Diyabalanage, S., Samarakoon, K. K., Adikari, S. B., \& Hewawasam, T. (2017). Impact of soil and water conservation measures on soil erosion rate and sediment yields in tropical watershed in the Central Highlands of Sri Lanka. Appl Geogr, 79, 103-114

Girma, M., \& Vijaya, B. (2015): Morphometric Characteristics and the Relation of Stream Orders to Hydraulic Parameters of River Goro: An Ephemeral River in Dire-dawa, Ethiopia University College of Sciences, Department of Geography and Geo-informatics, Osmania University, India 2015

Mphoweh, J. N., \& Futonge, N. K. (2009). Drainage and Drainage Basin of Cameroon.

Ndenecho, E. (2012). Freshwater and Coastal Resource Management in Cameroon, Building Resistance and Resilience to Climate Change. ISBN978-9952-621-06-4.

Oyatayo, K. T., Bello, I., Ndabula, C., Godwill, G. J., \& Ademola, S. J. (2017). A Comparative Analysis of Drainage Morphometry on Hydrologic Characteristics of Kereke and Ukoghor Basins on Flood Vulnerability in Makurdi Town, Nigeria. Hydrology, 5(3), 32-40. http://dx.doi.org/10.11648/j.hyd.20170503.11

Sarita, G. (2015). Morphometric Analysis of a Shakkar River Catchment Using RS and GIS. International Journal of $u$ - and e- Service, Science and Technology, 8(2), 11-24. http://dx.doi.org/10.14257/ijunesst.2015.8.2.02

Tumpa, M., \& Srimanta, G. (2015). Evaluation of Morphometric parameters of drainage networks derived from Topographic Map and Digital Elevation Model using Remote Sensing and GIS. International Journal of Geomatics and Geosciences, 5(4).

Waikar, M. L., \& Aditya, P. N. (2014). Morphometric Analysis of a Drainage Basin Using Geographical Information System: Available online 25 February 2014, Vol.2 (Jan/Feb 2014 issue)

Yahya, F., Omar, A., \& Ali, S. (2016). Morphometric Analysis and flash floods assessment for drainage basins of the Ras En Naqb Area, South Jordan using GIS. Journal of Geoscience and Environment Protection, 14, 933.

Zhu, B., Li, Y., Yue Y., \& Yang Y. (2017). Aggravation of North Channels' Shrinkage and South Channels' Development in the Yangtze Estuary under Dam Induced Runoff Discharge Flattening. Estuarine, Coastal and Shelf Science, 187, 178-192.

\section{Copyrights}

Copyright for this article is retained by the author(s), with first publication rights granted to the journal.

This is an open-access article distributed under the terms and conditions of the Creative Commons Attribution license (http://creativecommons.org/licenses/by/4.0/). 